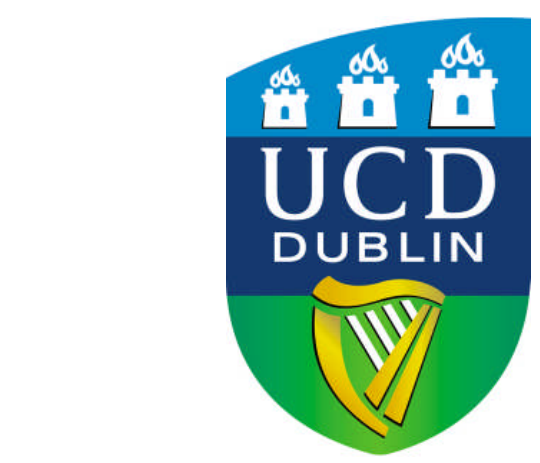

UCD GEARY INSTITUTE

DISCUSSION PAPER

SERIES

\title{
The Politics of Economic Adjustment in a Liberal Market Economy: the Social Compensation Hypothesis Revisited
}

\author{
Niamh Hardiman \\ UCD School of Politics \& International Relations \\ Niamh.Hardiman@ucd.ie \\ Patrick Murphy \\ UCD School of Mathematical Sciences \\ Patrick.Murphy@ucd.ie \\ Orlaith Burke \\ PhD Candidate, UCD School of Mathematical Sciences \\ Orlaith.Burke@ucd.ie \\ $04^{\text {th }}$ February 2008
}

This paper is an output of the IRCHSS-funded research project Mapping the Irish State, based in UCD Geary Institute. The views expressed here do not necessarily reflect those of the Geary Institute. All errors and omissions remain those of the author. 


\section{Introduction}

Ireland's path toward integration in the international and specifically the EU economy has been punctuated by painful experiences of economic and social crisis. Since the turn toward trade liberalization in the early 1960s, none was more severe than the extreme fiscal difficulties, high unemployment, mass emigration, and towering public debt problems of the 1980s. These gave rise to a concerted stabilization of the public finances, supported by the initiation of institutions and practices of social partnership. Originating in the experience of economic crisis, these have now lasted some twenty years. But underlying these twists and turns we detect strong underlying features in the policy of adjustment to new international pressures, most prominently perhaps a consistent and coherent industrial development policy (Bradley 2000; 2004; FitzGerald 2000). This paper explores some puzzles arising from what we perceive as the underlying consistency in Ireland's manner of adjustment to trade liberalization.

The Irish economy underwent a profound transformation in the composition of economic activity between the 1960s and the 1990s. This might have been expected to create significant dislocations for different sectors in the economy and indeed to have presented some difficulties for governments promoting these changes. Comparative literature suggests that trade liberalization is likely to give rise to a set of complementary domestic policies - to 'compensate' domestic interests, both producer and worker interests - for these challenges. But we do not detect the pattern of association between trade liberalization and policy interventions in Ireland that would be predicted by the core literature on this subject. This is not to say that transfer social spending or supports to domestic industry were absent; rather, they were not put in place on a comparable scale to other countries. We suggest that this is due in part to constraints on government policy arising from the timing of Ireland's integration into the international economy, and specifically into the EU with its marketbuilding emphasis. We also wish to suggest that this is explicable in terms of domestic politics, the profile of winners and losers, the divisions between and within sectors, and the way their interests were represented politically. We do not see a purely market-driven process of policy change: domestic institutions continuously mediate the impact of international economic integration on national interests. 


\section{Economic openness and its political consequences}

The decades from the end of the Second World War to the mid-1970s constitute a distinct phase in European political economy. The dominant policy stance during this period has been termed 'embedded liberalism' (Ruggie 1982), combining international trade openness with what in many countries was experienced as strong domestic interventionism by governments committed to the 'Keynesian welfare state'. As Polanyi had noted of the $19^{\text {th }}$-century highwater era of free-market capitalism, 'laissez-faire was utopian; ...stopped by the realistic self-protection of society' (Polanyi 1944/1975, p.141). That is to say, organized labour sought to restrain the effects of unfettered market activity, and to ensure statutory regulation of working conditions and some assurance of minimum income entitlements. Where stable political compromises had not been possible in the early part of the $20^{\text {th }}$ century, there had been a slide toward protectionism, authoritarian nationalism, and fascism, which in turn provided the context for the devastations of the Second World War (Block 2001). In the postwar decades, the reconstruction of international trade relations and the expansion of the scope of the market meant a growing exposure of more employees to the hazards that ensue from integration into the international economy. Hence, according to this argument, we see international economic liberalism going hand in hand with improved social protection.

Within this general trend much variation can be identified. One strand of analysis holds that small states displayed a particular pattern of adjustment to growing integration in the international economy. Cameron, for example, noted a strong inverse correlation between the size of the economy and the volume of the 'public economy': small states tended to have large public sectors (Cameron 1978). He argued that this was attributable to the tendency of small countries to develop highly concentrated industrial sectors, which would be conducive to a centralized or coordinated approach to wage formation, which would in turn strengthen trade union political influence and the electoral basis of left-wing governments: an analysis that closely matched the Swedish experience in particular. Authors such as Ruggie and Rodrik have argued that the 'compensation hypothesis' was not confined to small countries, but extended to all countries in virtue of their exposure to greater economic insecurity arising from trade liberalization (Rodrik 1998; Ruggie 1982). 
Katzenstein demonstrated that that the small European states that featured both a mature industrial sector and stable democracy 'complemented their pursuit of liberalism in the international economy with a strategy of domestic compensation' (Katzenstein 1985, p.47). He noted two models: one took the form of building large welfare states in response to labour strength, as in Sweden; alternatively, he identified a more business-friendly policy combination, as in Switzerland, under a highly regulated form of economic management. This distinction between a Social Democratic and a business-led variant of small open economy adjustment applied only to European countries that were already highly developed and with a sizeable industrial sector by the 1970s. Poorer countries such as Ireland and Finland, and recently democratized countries such as Portugal and Greece were thus explicitly excluded from consideration.

During the 1990s, questions began to be raised as to whether there was any future for such distinctive patterns of economic adjustment. Growing international capital mobility, the internationalization of production, increased volumes of trade, imposed new constraints on governments' macroeconomic policies, especially for leftist governments who most depended on maintaining fiscal policy autonomy. Tighter fiscal constraints put limits to what welfareoriented governments, whether Social Democratic or Christian Democratic in composition, might be able to achieve (Iversen and Wren 1998; van Kersbergen 1995). And yet globalization did not force convergence on a uniform neo-liberal policy prescription. Governments may indeed have been more constrained, but there was still a choice available. As Ruggie commented, where fiscal policy is under pressure, 'The prudent course of action... is to "review and redesign" the social safety net, not simply to "slash and trash" it' (Ruggie 1997, p.10).

The nature of the choices continued, as before, to be mediated by the profile of domestic economic interests and the pattern of their interactions within the domestic political institutional context. Garrett's cross-national analyses concluded that in countries where Social Democratic politics was already well established - with strong leftist governments with a long tradition of government incumbency, and powerful trade unions capable of coordinating their collective action - globalization actually increased rather than diminished the incentives for government to continue to pursue an interventionist policy combination (Garrett 1998). There is no evidence for the 'efficiency hypothesis' (Garrett 1995, p.640) - 
that is, the claim that international competitiveness pressures alone will squeeze the role of state spending on expansionary and interventionist policies.

But most countries fall into some mixed category, where the balance of power did not shift in any uniform or simple direction. Rather, new coalitions of interests opened up in sometimes unexpected ways. The growth of the services sector that was more resistant to unionization, the increase in part-time and temporary work, often associated with the expansion of women's employment, the and the continuing strength of unions in the public sector, fragmented organized labour and made it harder for unions to work to a single agenda in wage bargaining. The preferences of export-oriented manufacturers increasingly diverged from those in sheltered sectors, resulting in a fragmentation of employer interests. New cleavages of interest cut across employer-labour lines within sectors, rather than across sectors on conventional class lines (Kinderman 2005; Pontusson and Swenson 1996; Swenson 1991).

But these trends were felt differently depending on the underlying economic structure. In liberal market economies (LMEs), with an institutional bias toward market-driven solutions to investment, growth, and pay determination, increased economic internationalization is likely to further strengthen a market-driven pattern of adjustment (Hall and Gingerich 2004; Hall and Soskice 2001; Soskice 1999). In coordinated market economies (CME), however, the existence of interlocking policy commitments may not make market-conforming outcomes the most preferred solution for actors within the system - or more accurately, perhaps, it will not necessarily be the solution to which they converge as the most desirable in the circumstances (Thelen 2000).

But the boundary lines between clusters of countries can be hard to delineate very clearly. And once again it may be that smaller states have discovered new and unexpectedly flexible ways of adjusting successfully to emergent economic challenges. For example, if labour market ridigity was one of the problems resulting from the growth of welfare states, addressing this has not necessarily resulted in 'workfare' on the British or US models, but may result in a more nuanced combination of labour market and social protection strategies, as in the case of Denmark's 'flexicurity' policy mix (Dingeldey 2007). Ireland is frequently cited along with Denmark, the Netherlands, and Finland, among smaller states with flexible 
yet welfare-friendly adjustment strategies (Annett 2007; Auer 2000; Schwartz and Becker 2005). And Ireland is one among a number of countries - again, not exclusively, but most significantly smaller states - that have sought to address issues about wage competitiveness and fiscal constraints, not by crushing unions or unleashing market forces, but within a bargaining context. The competitiveness agenda is prominent in these new social pacts, but so too is a concern with social equity, in what has been termed 'competitive corporatism' (Avdagic et al. 2005; Molina and Rhodes 2002; Rhodes 1998).

All these perspectives on how states - and especially small states - adapt to growing trade exposure provide the framework for us in which to analyse the Irish experience. We need to consider how a small country that has close affinities with the Anglo-American style of capitalism, but which is also intensifying its trade links with continental Europe, has responded to the challenge of increased exposure to international trade and increased integration into the international economy.

We recognize that a broad differentiation of types of capitalism is persuasive. But the typologies are only guides to understanding: we must bring back into view both the potential for active policy innovation, and the variations in scope for domestic coalition-building behind different policy options.

From the literature, we would expect to find some evidence of the compensation hypothesis in Ireland. That is, we would anticipate that Ireland's increasing trade liberalization and growing integration into the international economy would result in evidence of offsetting state expenditures and interventions. The compensation hypothesis suggests that governments will spend not only on cash-based social transfers (unemployment and other benefits), but also on positive welfare enhancements such as improved social services, and on aids to domestic industry to help them adapt (Katzenstein 1985; 2003). Indeed, new growth theory underpins some of this logic, suggesting that government spending on improving productive assets in areas such as education and human capital, physical infrastructure, and research and development, by boosting productivity, supports rather than undermines growth potential (Barro and Sala-I-Martin 1995). Whether and to what degree, then, Ireland's experience conforms to the compensation hypothesis is the next step in our discussion. 


\section{Ireland's openness in comparative context}

In 1960, Ireland had experienced almost twenty years of protectionist policies and an attempt at import-substituting industrial development. It had missed out on the first decade of postwar European trade expansion: some $40 \%$ of the workforce was engaged in agriculture; most industrial production was small-scale and intended for the domestic market; Britain was virtually the sole trading partner (Kennedy et al. 1988). In 1960, the value of imports and exports as a proportion of Irish GDP was about 55\%. Following the turn toward trade liberalization export orientation, and policies more favourable to inward investment from about 1960 on, economic openness began in increase, then took a sudden leap upward after EEC membership in 1973 (see Fig. 1).

Fig. 1 about here.

By the early 2000s, Ireland was one of the most open economies in the developed world, with a ratio of imports plus exports to GDP of $98 \%$, and $118 \%$ in relation to GNP. The Netherlands stood at $97 \%$, Austria at $71 \%$ and Sweden at $62 \%$, and New Zealand at $44 \%$. The USA stood at 19\%, Britain at 39\%; the EU15 average was 54\% (OECD Economic Outlook 2004 - see Fig. 2 below). Indeed, on another measure, Ireland consistently appeared in the top three globalized states in the world in the Foreign Affairs/ Kearney Index of Globalization during the 2000s. (See, for example,

http://www.foreignpolicy.com/users/login.php?story_id=2493\&URL=http://www.foreignpoli cy.com/story/cms.php?story id=2493\&page=7).

Fig. 2 about here.

Irish public spending in 1960 was relatively low in comparative terms. Government current expenditure, measuring all non-capital government activity including social transfers and social spending, grew steadily thereafter, as Fig. 3 shows. The trend shows marked dips at intervals, especially during the phase of fiscal retrenchment in the late 1980s - but in real terms, the trend is consistently upward.

Fig. 3 about here. 
In comparative perspective, though, Ireland has not been a high spender. Starting from quite a low base in 1960, and even allowing for the steady upward trend in spending in real terms, public spending in general and spending on social transfers, social services, and other forms of welfare provision, stayed at an overall relatively low level. During the 2000s, for example, we can see that government consumption expenditure - whether measured as a proportion of GDP or of GNP - is very much at the lower end of the OECD spectrum, as Fig. 4 shows.

Fig. 4 about here.

And relatively to the trend lines in other OECD countries - including smaller European states - it has been consistently at the lower end of the distribution, as Fig. 5 shows (and although this only indicates spending in relation to GDP, looking instead at GNP does not alter Ireland's relative position significantly).

Fig. 5 about here.

On the face of it, the evidence is mixed: comparative low spending rates, but increasing rapidly in absolute terms. To what extent, then, can we identify evidence for the compensation hypothesis in Irish political economy? Our initial analysis seeks to find underlying patterns in the way states respond to common challenges over time. We seek to test whether or not there is any deep association between openness and government spending response.

To do this we constructed a time series of some key variables. We undertook a cointegration analysis of how these may have covaried over time across countries; this proved inconclusive because of the complexity of the interactions being modelled. We therefore explored another way of analysing how countries might cluster, if at all, in the underlying dynamics of their responses to growing economic openness, based on averaging the associations as ratios for each decade.

First we constructed a measure of 'Economic Openness', defined as the sum of exports and imports expressed as a proportion of GDP (or GNP for Ireland - though we found that using one or the other measure did not affect the overall findings significantly). We constructed this measure for 17 countries for every year from 1970 to 2005 . 
We would anticipate that one of the characteristic responses in a small open economy would be an increase in state supports to domestic industry to enable them to adapt to the more hazardous market environment. This is measured in terms of Gross Fixed Capital Formation, plus industrial subsidies.

We would also anticipate that growing openness would result in an increase in social spending, again in line with Katzenstein's observation that those most exposed to increases in market hazards would seek stronger protection. We took the standardized OECD definition of social benefits as the appropriate measure. We then constructed a measure of 'Government Intervention' that synthesized these two strands. As with all our variables, this was computed for every country for every year.

We then constructed a measure of social vulnerability, to assess the extent of the demands being made on governments. This is defined as a combination of age- and youth-dependency (over 65 and under 15), plus those who were unemployed. This is a measure of 'Social Need'. The next step in this phase of the analysis was to compute a ratio of 'Government Intervention' to 'Social Need', to give a measure of spending by government relative to those in need in the society. This we define as a measure of 'State Effort'.

Finally, we constructed a measure of 'State Effort' in relation to 'Economic Openness'. This gives us a final time series of 'State Response to Openness'. This measures the extent to which public compensation (capturing industrial supports as well as cash transfers), per dependent individual in the population as defined above, increases with each additional incremental degree of economic openness. We then averaged the evidence of this series, and analysed how this compared country by country. Three clusters emerge clearly, as Table 1 shows.

Table 1 about here.

What we take this to mean is that in the countries with a high score on 'State Effort', public spending on the range of 'compensatory' issues is considerably greater than would have been expected from the overall profile of countries' responses to economic openness. For each incremental experience of economic openness, Sweden, Denmark and Norway have responded with much greater 'Government Intervention' in relation to 'Social Need' than the 
generality of countries. In the medium-scoring countries, patterns vary considerably, but within a broadly comparable range.

In the lowest-scoring group of countries, the association between our variables shows that 'Government Response to Openness' is particularly weak. In this analysis, Ireland clusters with the less-developed countries of Southern Europe in its pattern of political responses to economic openness. We find that Britain is most appropriately situated in this category too relative to its openness, its level of state spending on industrial supports and social compensation has been less than would have been expected from the general trend across all societies. Belgium is something of an anomaly here: on the standard measures, its economy is exceptionally open, mainly in view of its role as an international administrative capital for the EU, with considerable levels of inflow and outflow of capital. In this sense, public spending is low relative to openness; we believe a different estimator of Belgian fiscal effort (including debt levels) and industrial composition would give a different and perhaps more realistic picture.

These findings suggest that averaged over a whole 35-year period, countries do tend to display some underlying strategic response to openness; and that they tend to group in broad terms. But Table 1 which reports these relationships as average trends over very different economic phases may be masking time-sensitive changes. Might it be the case that Ireland's relative ranking changes over time? For example, it may be that in the early phase of slower trade liberalization during the 1960s, when Ireland was also relatively poor in comparative terms, welfare effort was still at quite low levels, but that this may have changed with greater trade openness. It may be that as Ireland became much wealthier during the 1990s, the level of 'State Effort' in relation to openness was much greater.

To explore these possibilities, we repeated the exercise described above for each ten-year average period starting in 1970, ie 1970-1979, 1980-1989, 1990-1999, and 2000-2006. While this periodization does not perfectly capture fluctuations in international economic business cycles, it does make it possible to differentiate our countries' experiences to some degree.

[Tables 2a, 2b, 2c, 2d, 2d, 2e, 2f, about here? Or in an Appendix?] 
In fact, as Tables 2a-f reveal, an analysis of openness by decade does not disrupt the groupings and makes only marginal changes to the rank-ordering of countries.

In order to understand what the sources of variation are across countries, we are compelled to look within countries at the variations in domestic institutional profiles and the strategic interactions of the main economic actors (Scharpf 1997). We also need to be sensitive to the dominant ideas and values that shaped their sense of what was politically possible - ideas can have an independent explanatory value, and 'discourse' can make a difference to how actors engage with one another (Blyth 2002; Hall 1997; Schmidt 2003). Why, then, does Ireland show so little evidence of the compensation hypothesis in action?

\section{The social compensation model in Ireland}

We might draw out two competing implications from the evidence outlined above. The first might be that the compensation hypothesis simply is not relevant to the Irish case: Irish governments did not behave in a manner consistent with the expectations that they would provide appropriate supports to ease and assist the process of adjustment to trade liberalization. This hypothesis does not seem compelling for two reasons. Firstly, we have already noted that government expenditure did indeed rise steadily. We do not see a minimalist government unleashing relatively untamed market forces. And secondly, in an established democracy, governments cannot be oblivious to the consequences of social dislocation where they occur, nor heedless of the possible electoral backlash that might arise from popular discontent.

An alternative hypothesis would suggest therefore that the aggregate trends we have noted are somehow not capturing more nuanced ways in which governments were in fact responding. This would suggest that we need to identify which were the most vulnerable sectors or interests, and look more closely at the nature and extent of compensation mechanisms directed toward them. But this line of analysis also required us to consider why Irish compensation mechanisms seem to have been more restricted, relative to the extent of openness, than has been apparent in other open economies. 


\section{Trade liberalization and 'Government Effort'}

We can identify two phases of trade liberalization in Ireland: the late 1950s to mid-1960s, which in practice had rather limited consequences; and the decision in 1972 to join the EEC along with Britain, which had significant consequences for Ireland's political economy. And while neither of these moments provoked any crisis, they opened a new development trajectory which in turn threw up a whole new set of adjustment pressures. If we are to identify periods of crisis, they may be seen to follow from failed or incomplete attempts to deal effectively with these, especially apparent in the problems of tax reform, and the poor management of fiscal policy. And insofar as a new workable policy framework was set up from 1987 on, we must also be attentive to the limitations and weaknesses of the deals arrived at.

Ireland had retained its protective tariff barriers well after the rest of Europe had moved toward trade liberalization. Although they had served the country well since the 1930 s in building up small-scale domestic industry, mostly to meet domestic demand, expert opinion warned that protection had outlived its usefulness after World War Two (Ó Gráda 1997). A phase of political instability made decisive reform difficult. But the seeds had been sown by thinking within the Department of Finance in particular for a reframing of policy options and a willingness to engage in tariff reduction (Girvin 1989).

Frank Barry has argued that the turn away from protectionism and toward trade liberalization can be understood quite readily in the context of comparative political economy literature that asks about how various groups' interests led them to defend different policy preferences (Barry and Weir 2007). The sequencing of policy change in the early 1960s had made foreign ownership relatively uncontentious, as this had already been adopted behind protective tariff walls. Preferential trade agreements between Britain and Ireland had already been negotiated under the Anglo-Irish Trade Agreements 1938 and 1948. These were strengthened by the modest tariff reduction agreement of 1960 and the subsequent Anglo-Irish Free Trade Agreement (AIFTA) of 1965. Foreign-owned companies from the mid-1950s onward, still a small sector, were strongly export oriented and supported further trade liberalization. But from the 1960s on, much of domestic manufacturing industry was recognized as being vulnerable if exposed to increased competition with British industrial goods. The same 
considerations applied when EEC membership was under consideration in the early 1970s. Industry would gain improved access to European markets, but the fact that indigenous firms were still largely oriented toward domestic and British markets made this less enticing a prospect.

Agricultural interests, still very important at this stage, changed their views over time. Farmers' support for the AIFTA was bolstered by the fact that the programmes for economic expansion, developed within the Department of Finance and adopted by the incoming Fianna Fáil government from 1957 onward, were predicated on an increase in agricultural production as the way to grow the Irish economy out of the deep recessions of the 1950s. The framing of the issue of EEC membership in 1972 was somewhat different. Agricultural interests could not afford to lose preferential access to British markets relative to Commonwealth countries. If Britain joined the EEC, Ireland must; and the prospect of agricultural subsidies to Ireland from the EEC was certainly attractive.

Government and opposition alike supported Ireland's EEC membership despite the fact that a coalition of domestic industry and the trade union movement opposed it. The logic of exportled growth prevailed over defence of the labour-intensive traditional manufacturing sector (O'Malley 1989). The dominant policy was now to grow domestic employment through increased flows of foreign direct investment (FDI). This would be made easier by having access to the wider European market. Low corporation taxes for exporting companies were already in place; the Industrial Development Authority (IDA) was the conduit of additional supports and subsidies to inward investors, especially into greenfield sites.

This analysis of the politics of trade liberalization highlights the challenges Ireland faced, first to cope with the relatively modest intensification of competitive pressures during the 1960s, then to the increased industrial competition arising from EEC membership in the 1970s. The 'completion' of the internal market in the EU from 1992 on represented the culmination of the adjustment strategies begun in the 1970s.

In fact we can identify distinctive policy responses, consistent with the compensation hypothesis, from the early 1960s on. Barry suggests that increases in public spending, especially public social spending, during the 1960s can be understood as the price undertaken by the Lemass government to secure the support of the trade union movement to the new 
strategy of market-oriented industrial development (Barry and Weir 2007). We might also see the government's active commitment to helping domestic industry to cope with new competitive pressures during the 1960s in a similar light. The employer-labour Committee on Industrial Organization, for example, aimed to bring business and union representatives together with academics to improved overall understanding of their respective positions and of the emergent economic challenges (Hardiman 1988). Other bodies such as An Foras Forbartha, An Córas Tráchtála, and AnCO, existed to help domestic manufacturers with marketing, exporting, and labour force needs. Periodic reviews and indeed in the early 1990s extensive reorganization of the functions of the Industrial Development Authority were undertaken to bring the needs of domestic industry into perspective and to assist their development (O'Sullivan 2000). From the 1970s on, domestic producers were actively encouraged to seek opportunities to provide upstream as well as downstream linkages with the new foreign, high-tech, export-oriented industries. There were phases when all this capital intensification and human capital development seemed to produce only 'jobless growth'. But by the boom period of the 1990s, this was generating much greater levels of successful startups and autonomous development of Irish-owned manufacturing and services, and correspondingly rapid employment generation opportunities (Barry et al. 1999; O'Malley 2004)

A flurry of social legislation in the early to mid 1970s has sometimes been understood as a form of catch-up in areas of income maintenance (Breen et al. 1990; Curry 2003; McCashin 2004). To some degree this can indeed be understood as a form of modernization, flowing from increased awareness of British and continental European social provision; but it might also perhaps be understood in the context of the real growth in economic insecurity attendant upon trade liberalization. It should be noted that the biggest single category of increased social spending during the 1970s was in the area of unemployment compensation, but the single biggest driver of this was not an expansion in entitlement or improved generosity of provision, but a surge in demand (Maguire 1984). Unemployment levels increased in response to the twin problems of the 1970s - the international oil-price crisis, and the job losses in the relatively uncompetitive domestic industry sector in the context of greater market exposure. 
The extreme fiscal problems of the 1980s, which is the period normally identified as the crisis era of modern Irish political economy, owe their origins to the patterns laid down during the 1970s. There was a persistent tendency to use fiscal policy in a pro- rather than countercyclical manner; in a very open economy there was going to be very little scope for Keynesian multiplier effects in any case. Deficit fiscal spending had been unknown in Ireland until the late 1970s, due in large part to the innate caution of the Department of Finance. Public spending responded strongly to the electoral cycle (Honohan 1992; 1999). Thus we see pro-cyclical trends in the political management of the economy from the early 1960s on, although this really only became apparent from the late 1970s when fiscal deficits were first used. Governments during the 1980s were obliged to attempt to correct these problems in the throes of international recession, so the effects of the downturn were further deepened by the fiscal imperative to respond, once again, pro-cyclically.

However, another element in the politics of domestic adjustment to new economic challenges was to engage organized economic interests with the policy process. Stabilization of fiscal policy was greatly facilitated by the national consensus created in the mid-1980s to cut debt levels and reduce fiscal deficits. Evidence of a bias toward tripartism is seen during the 1960s, but only became established and even institutionalized from 1987 on (O'Donnell and O'Reardon 2002).

Adaptation of employer-relations in Ireland falls into a difficult middle-zone. Where unions are well-organized, the logic of collective action suggests that they may well face incentives to adopt an 'overarching' strategy in their approach to pay bargaining with employers (Olson 1971). They may be willing to negotiate national or industry-level pay agreements in a broader context of economic stabilization, possibly eased by the provision of offsetting or compensating policy commitments by government - the Swedish model for much of the postwar period (Pontusson 1992). Where unions are weakly organized, or highly decentralized, especially in liberal market economies, there may be scope for employers, supported by government, to engage in market-driven marginalization of unions from wagesetting influence - the British strategy during the 1980s (Garrett 1993). Either of these options might produce good performance on indicators such as inflation, unemployment, industrial conflict. A particularly difficult challenge to economic management arises in situations where unions are well organized but not highly coordinated or centralized, and 
employer interests are diverse and not well coordinated. In this context, discrete bargaining groups can seek to press their advantage to the full. But the cumulative effect of doing this may well be to increase the incidence of industrial conflict, pushing up wage inflation, and especially in the context of small open economies that are obliged to be price takers on the international market, and where exchange rate policy is not readily negotiable - resulting in loss of competitiveness and consequently unemployment (Calmfors and Driffill 1988). All the more so when exchange rate policy is either unavailable or of limited use, as was the case in Ireland due to the link with sterling until 1979, membership of the EMS during the 1980s, and acceptance of the disciplines attendant on preparation for and then participation in the Euro after 1992 (Crouch 2000).

In a pluralist and diverse industrial relations system such as Ireland had inherited from Britain, the scope for autonomous employer-labour consensus-seeking was always relatively weak. Initiatives to manage industrial conflict and to shape the terms of pay negotiations have typically come from government intervention. As early as 1941, Fianna Fáil sought to introduce new legislation to rationalize trade union organization, recognition, and bargaining rights. This failed, leaving organizational diversity and a division between British-based and Irish-based unions (MacCarthy 1977). But it paved the way for the establishment in1946 of the Labour Court, which sought to exercise significant influence over pay determination over the following two decades. And even when it foundered in the face of wage competition, fragmented bargaining, and mounting industrial conflict in the late 1960s, the principle of government initiative in shaping employer-union negotiations was already in the policy repertoire.

Ireland's two phases of recourse to negotiating centralized national-level framework pay deals on a tripartite basis should therefore be seen as part of the politics of domestic compensation. The first, from 1970 to 1981 , came to an end due to employer resistance to wage drift, and a recurrence of widespread industrial conflict in the context of uncertain fiscal prospects. From 1981 to 1987, years of fiscal crisis, extraordinarily high unemployment, and the return of large-scale emigration, there seemed to scope for and no prospects for anything other than decentralized pay bargaining. The return to national-level negotiation of social pact-like deals, through social partnership mechanisms, is generally seen as a turning point in that phase of economic crisis. The first social partnership deal in 1987, trading wage restraint 
for tax cuts, to stabilize public debt and reduce inflation, was understood on all sides as a crisis-management mechanism (Hastings et al. 2007). The positive feedback effects helped consolidate confidence and facilitated the institutionalization of a wider range of support mechanisms for a broadening set of interlinked policy discussions, producing deals of approximately three years' duration (Hardiman 2002; 2006).

The Irish industrial relations system diverged significantly from the British during the 1980s despite its family affinities. Since Ireland also falls into the category of liberal market economy, this might be surprising. But in the context of our discussion of the relationship between trade liberalization and domestic compensation, the recurrent interest in some form of bargained pay deal becomes more understandable. Small open economy incentives came into play: government sought to mediate market-based conflicts and to support a coordinated industrial relations response to new economic hazards.

\section{Explaining the limits to the compensation hypothesis}

We have seen that it is possible to identify a more targeted but still real state role in putting in the supports for economic adjustment to trade liberalization. But these appear to have produced a significantly lower level of state effort than would have been anticipated, both from theoretical expectations and from comparative experiences. Why, then, was 'state effort' at a relatively low level in Ireland? A number of explanations can be proposed. Firstly, the core logic of the proposition about trade liberalization could itself be opened to question. The alignment of interests arising from the changing economic structure needs to be analysed more closely. And secondly, the politics of accommodation at the heart of social partnership need to be explored more fully.

The proposition that increased trade liberalization is linked with more compensation mechanisms assumes that greater openness makes economic performance more volatile, such that governments either respond to electoral pressure for relevant protection, or act in anticipation of such pressure. But it may be the case, that a deepening of international economic integration actually stabilizes economic fluctuations affecting those in the exposed sector of the economy (Down 2007). In the Irish case, while domestic manufacturing suffered severely - all but wiping out most traditional industry -what was accomplished through greater economic openness over the course of forty years was nothing short of a profound 
restructuring of the economy. Trade openness made it possible to generate whole new industrial sectors, through a combination of FDI and spinoff domestic enterprise (Barry and Bradley 1997). The result was a wholesale upgrading of the employment structure and an ongoing impetus toward increasingly knowledge-intensive and high-tech investments, the virtual elimination of unemployment, and a rapid increase in women's employment, as well as a convergence in average incomes toward north-west European averages by the early 2000s (O'Connell 2000; O'Connell and Russell 2007; Ó Riain 2004). The result was that by the 2000s about half of all employment in manufacturing and the great majority of exports were accounted for by foreign-owned firms, mostly American. A growing share of both employment and exports came from internationally traded services, both Irish and foreignowned. Openness was experienced as opportunity as well as threat.

These changes in the composition of the economy have a bearing on the representation of interests and their articulation into both social partnership and party political representation. The cleavage structure in Irish politics cut across class lines for the most part, and the Labour Party, while entirely comparable with other European Social Democratic parties, attracted the smallest support base among European countries (Mair 1992). The strong and pervasive influence of the Catholic Church had also made it difficult, in a relatively poor and largely agricultural society, for progressive or redistributive politics to make much inroad. Governments had an incentive to build cross-class coalitions of support; but the centre of gravity in policy profiles was toward the centre-right, reflecting the distribution of voter preferences (Benoit and Laver 2005; Laver 1992). There was relatively little scope for the politics of welfare state expansion along conventional Social Democratic or Christian Democratic lines. Welfare spending - on both transfers and services - increased rapidly during the 1990s and 2000s; but income inequality grew, transfers did not track wages, and services continued to trail in quality relative to countries of comparable wealth (Layte et al. 2004; Nolan and Maitre 2007; Whelan et al. 2007).

Social partnership agreements must be understood in this context too. The composition and profile of the trade union movement helps to account for the terms on which it participated in partnership structures. During the 1970s, the more extreme fragmentation of the trade union movement from earlier times had started to be overcome through a combination of a drive from the trade union leadership and changes in industrial relations legislation. But 
coordination of pay policy across the trade union movement proved difficult, because what was emerging was a two-tier employment structure. Wage leadership, in effect, was now exercised by the newly expanding high-tech, export-oriented, and mostly foreign-owned sector. But this was very much more profitable than the more sheltered domestic sector, and leapfrogging pay demands were further driven by the highly interlocking structure of public sector employments. This limited the effectiveness of pay coordination during the first phase of national wage agreements (Hardiman 1988).

By the late 1980s and the 1990s, the profile of employment had changed considerably. While trade union numbers had held up well, trade union density had slipped to about $40 \%$, as unionization had not kept pace with rapidly growing employment opportunities: estimates of private sector unionization were sometimes as low as $10 \%$, while up to $80 \%$ of the public sector was unionized and about half of all union members were public sector employees (Hardiman 2006). The new wave of service industry, both high-end and less skilled, tended to be weakly unionized, especially in the context of a highly buoyant labour supply. Most of the new crop of high-tech companies were now non-union employers (Gunnigle et al. 2005). Union recognition was a thorn in the side of the trade union leadership and a recurrent issue of principle for them, though not necessarily a felt grievance among most of the workforce concerned. The exporting sector was no longer a generator of above-the-norm pay claims partly because it was itself subject to intensified global competitiveness pressures and was largely content to conform to local pay norms; but partly too because it could avail of company-level pay flexibility through discretionary means such as bonuses and other schemes (Roche and Geary 2000). Pay agreements were therefore principally negotiated by the public sector, construction, banking, and Irish-owned manufacturing. By and large the pay deals held. But the diversity of the labour force, the emergence of a multi-speed economy, and composition of trade union membership frequently put the construction of a coherent pay policy under severe pressure, as Table 3 illustrates.

The main focus of union as well as employer involvement in social partnership agreements was therefore on disposable income. Martin Rhodes has termed such deals 'competitive corporatism', since while social pacts were still about protecting workers from the full rigours of market disciplines, unions had accepted the logic of business imperatives, often in highunemployment contexts (Rhodes 1998; 2001). Ireland's pay pacts did not very strongly 
resemble the social pacts in other small European economies such as the Netherlands or Denmark in the 1990s, where employer-union deals were negotiated bilaterally, but where strong union and employer involvement in reforming welfare services went together with commitment to competitiveness-enhancing measures (Traxler 2004). The development of Irish social services remained largely outside the influence of unions and employers alike, in spite of the existence of myriad social partnership working groups, the National Anti-Poverty Strategy, and similar initiatives (Hardiman 2006). Unions could lobby to keep issues on the political agenda. But governments could pick and choose which issues to prioritize; the social partners had no institutional access to either the planning or the delivery of income maintenance or other social services schemes.

The 1970s pay deals had been focused on securing pay deals above the level of inflation. The social partnership deals of the 1980s and 1990s were based on tax cuts in exchange for wage moderation. The emphasis may have shifted from headline pay increases to disposable income, but individuals' assessments of the impact on their own incomes were decisive.

So politically mediated offsets for wage restraint did not take the form of collective consumption, or the social wage, that is, building up the welfare state, unlike the way in which the logic of domestic compensation played out in, for example, the Nordic countries. Rather, it took the form of tax cuts, improvements in household disposable income, and individual financial well-being. The trade union leadership adopted these priorities because they were constrained by the distribution of preferences among their membership. The pay deals were legitimated and bedded down by putting the deals to a ballot of members (Baccaro and Simoni 2002). Like voters more generally, welfare spending and welfare services are valued, but do not feature strongly as electoral issues or personal motivators in electoral choice. We have relatively little Irish evidence of whether or in what ways preferences for welfare spending might vary by employment sector, of the sort that exists for other countries (Balcells Ventura 2004). But there seems to be little basis either in Irish public attitudes or in Irish political discourse for the politics of redistribution or collective consumption (Hardiman et al. 2006; Hardiman and Whelan 1994). 


\section{Conclusion}

This paper found that the aggregate comparative evidence points toward Ireland being out of line with the expectations of the compensation hypothesis. Although it is a small open economy that underwent a rapid extension of trade liberalization, accompanied by rapid transformation of the employment structure, compensation spending did not keep in line with what would have been predicted.

We have suggested that this can be explained in two ways. Firstly, compensation strategies were indeed put in place, but their fiscal visibility is lower than elsewhere. And we need to take account not only of spending measures, but also of the strategic reorientation of industrial relations out of the experience of profound crisis and national economic vulnerability. Consensus orientation and conflict management strategies feature strongly in Irish political culture, and have to be understood not only or even primarily as a product of nationalist ideology, but as rooted in the incentives flowing from the country's political economy.

Secondly, the reasons why 'state effort' was lower than comparative trends might have indicated need to be explored further. We have suggested that Ireland entered its phase of economic modernization and industrial development with a policy inheritance of targeted and means-tested social welfare and a conservative orientation toward the redistributive capacity of the state. Governments did indeed undertake policies consistent with the compensation hypothesis. But we have suggested that the scope of their further choices was constrained by two further considerations: by the very conditions of the industrialization strategy that had been adopted by all parties, and by the nature of partisan mobilization around issues of left and right. Ireland was a liberal market economy with a heavy reliance on FDI and a policy mix based on maintaining low corporation tax. It cannot be said that a probusiness and pro-competitiveness policy mix was consistently adopted; the loading of the tax burden onto employees during periods of acute fiscal difficulties was an easy political option, though one resented and resisted by employers. Nevertheless, the policy preferences of business interests, including influential American investors, constrained the possibilities governments were willing to consider about the behaviour of the labour market and the rights of trade unions. Finally, neither the party system nor the industrial relations system was well 
adapted to making issues of welfare state expansion a central priority. The Irish model, with its combination of pro-business supports in a liberal market economy, with a social partnership system that, while delivering primarily on individualist interests, also kept collective employee interests in view, represented a distinctive strategy of adjustment to trade liberalization and integration into the European and global economy. 
Table 1. State Response to Openness, 1970-2005.

\begin{tabular}{|l|l|}
\hline LOW SCORE & \\
\hline Belgium & 0.81 \\
\hline Portugal & 2.06 \\
\hline Ireland & 5.06 \\
\hline Greece & 5.97 \\
\hline UK & 7.98 \\
\hline MEDIUM SCORE & \\
\hline Spain & 11.51 \\
\hline Netherlands & 15.08 \\
\hline Italy & 25.24 \\
\hline Finland & 28.02 \\
\hline NewZealand & 26.56 \\
\hline Austria & 30.21 \\
\hline France & 36.25 \\
\hline Australia & 67.65 \\
\hline US & 73.40 \\
\hline HIGH SCORE & \\
\hline Sweden & 206.11 \\
\hline Denmark & 265.45 \\
\hline Norway & 268.87 \\
\hline
\end{tabular}

Variables used in calculating these indicators:

1. Economic Openness =

(Imports plus Exports) / GDP, or GNP

2. Government Intervention $=$

Gross Fixed Capital Formation, plus industrial subsidies, plus Government Social Expenditure

3. Social Need $=$

Age Dependency (65+), plus Youth Dependency (0-14), plus Unemployed

4. State Effort=

(Government Intervention) / Social Need

5. State Response to Openness =

State Effort / Economic Openness

Date drawn from: OECD Economic Indicators 
Tables 2 a-f. Comparative Performance: rate of change, and profile by decade

Table 2a. GDRatio/Openness: Total

\begin{tabular}{|l|l|}
\hline Country & Total Mean \\
\hline Ireland & 7.593 \\
\hline Belgium & 10.375 \\
\hline Portugal & 11.776 \\
\hline Greece & 14.388 \\
\hline Netherlands & 16.680 \\
\hline UK & 17.637 \\
\hline Spain & 21.082 \\
\hline Finland & 25.438 \\
\hline Austria & 26.250 \\
\hline NewZealand & 28.967 \\
\hline Italy & 30.877 \\
\hline France & 31.788 \\
\hline Australia & 51.697 \\
\hline US & 101.439 \\
\hline Denmark & 205.278 \\
\hline Sweden & 258.132 \\
\hline Norway & 265.672 \\
\hline
\end{tabular}

Table $2 \mathrm{~b}$. Rate of change

\begin{tabular}{|l|l|}
\hline Country & Slope \\
\hline Belgium & 0.378 \\
\hline Netherlands & 0.514 \\
\hline Ireland & 0.776 \\
\hline Austria & 0.798 \\
\hline UK & 0.839 \\
\hline Portugal & 0.840 \\
\hline Finland & 0.973 \\
\hline Spain & 1.196 \\
\hline France & 1.289 \\
\hline Greece & 1.548 \\
\hline Italy & 1.576 \\
\hline NewZealand & 1.695 \\
\hline Australia & 2.955 \\
\hline US & 3.169 \\
\hline Sweden & 7.595 \\
\hline Denmark & 8.186 \\
\hline Norway & 14.797 \\
\hline
\end{tabular}


Table 2c. 1970s

\begin{tabular}{|l|l|}
\hline Country & 70s Mean \\
\hline Portugal & $*$ \\
\hline Ireland & 1.555 \\
\hline Greece & 1.732 \\
\hline UK & 2.977 \\
\hline Spain & 3.426 \\
\hline Belgium & 5.837 \\
\hline Italy & 6.002 \\
\hline NewZealand & 6.546 \\
\hline Finland & 7.969 \\
\hline Netherlands & 10.929 \\
\hline Austria & 11.735 \\
\hline France & 11.753 \\
\hline Australia & 17.191 \\
\hline US & 36.668 \\
\hline Sweden & 70.865 \\
\hline Norway & 74.109 \\
\hline Denmark & 76.594 \\
\hline
\end{tabular}

Table 2d. 1980s

\begin{tabular}{|l|l|}
\hline Country & 80s Mean \\
\hline Portugal & 3.536 \\
\hline Greece & 4.794 \\
\hline Ireland & 4.934 \\
\hline Belgium & 9.492 \\
\hline UK & 10.098 \\
\hline Spain & 10.569 \\
\hline Netherlands & 14.458 \\
\hline Italy & 20.080 \\
\hline Austria & 23.654 \\
\hline NewZealand & 24.960 \\
\hline Finland & 26.178 \\
\hline France & 29.694 \\
\hline Australia & 46.722 \\
\hline US & 72.097 \\
\hline Denmark & 171.670 \\
\hline Sweden & 184.535 \\
\hline Norway & 196.794 \\
\hline
\end{tabular}


Table 2e. 1990s

\begin{tabular}{|l|l|}
\hline Country & 90s Mean \\
\hline Ireland & 8.693 \\
\hline Portugal & 13.892 \\
\hline Belgium & 14.374 \\
\hline UK & 18.852 \\
\hline Netherlands & 19.692 \\
\hline Greece & 20.304 \\
\hline Spain & 23.335 \\
\hline Finland & 35.264 \\
\hline Austria & 37.072 \\
\hline NewZealand & 37.737 \\
\hline Italy & 39.554 \\
\hline France & 43.906 \\
\hline Australia & 64.706 \\
\hline US & 96.646 \\
\hline Denmark & 288.428 \\
\hline Sweden & 304.007 \\
\hline Norway & 321.954 \\
\hline
\end{tabular}

Table 2f. 2000s

\begin{tabular}{|l|l|}
\hline Country & 00s Mean \\
\hline Belgium & 15.114 \\
\hline Ireland & 20.256 \\
\hline Netherlands & 21.895 \\
\hline Portugal & 21.983 \\
\hline UK & 25.990 \\
\hline Greece & 33.077 \\
\hline Spain & 34.853 \\
\hline Austria & 36.728 \\
\hline Finland & 36.947 \\
\hline Italy & 46.846 \\
\hline France & 48.478 \\
\hline NewZealand & 49.973 \\
\hline Australia & 95.815 \\
\hline US & 129.278 \\
\hline Sweden & 304.337 \\
\hline Denmark & 315.732 \\
\hline Norway & 469.090 \\
\hline
\end{tabular}


Table 3. Labour costs - sectoral variations

\begin{tabular}{|l|l|l|l|l|l|}
\hline & Industry & Construction & $\begin{array}{l}\text { Public } \\
\text { Sector }\end{array}$ & $\begin{array}{l}\text { Distribution } \\
\text { and } \\
\text { Business } \\
\text { Services }\end{array}$ & $\begin{array}{l}\text { Banking } \\
\text { and } \\
\text { Financial } \\
\text { Services }\end{array}$ \\
\hline $\mathbf{2 0 0 0}$ & $6 \cdot 6$ & $12 \cdot 4$ & $5 \cdot 7$ & $8 \cdot 3$ & $6 \cdot 2$ \\
\hline $\mathbf{2 0 0 1}$ & $8 \cdot 0$ & $8 \cdot 7$ & $9 \cdot 9$ & $8 \cdot 0$ & $10 \cdot 9$ \\
\hline $\mathbf{2 0 0 2}$ & $6 \cdot 5$ & $9 \cdot 9$ & $4 \cdot 8$ & $3 \cdot 4$ & $4 \cdot 4$ \\
\hline $\mathbf{2 0 0 3}$ & $6 \cdot 8$ & $4 \cdot 2$ & $4 \cdot 3$ & $4 \cdot 6$ & $1 \cdot 6$ \\
\hline $\mathbf{2 0 0 4}$ & $4 \cdot 7$ & $4 \cdot 8$ & $8 \cdot 5$ & $5 \cdot 1$ & $5 \cdot 6$ \\
\hline $\mathbf{2 0 0 5}$ & $3 \cdot 6$ & $7 \cdot 2$ & $5 \cdot 9$ & $4 \cdot 1$ & $4 \cdot 3$ \\
\hline
\end{tabular}

Source: Central Bank Quarterly Bulletin, No. 4, 2006 (October), Table E5, p.92. 
Fig. 1. Irish Trade Openness, 1960-2002.

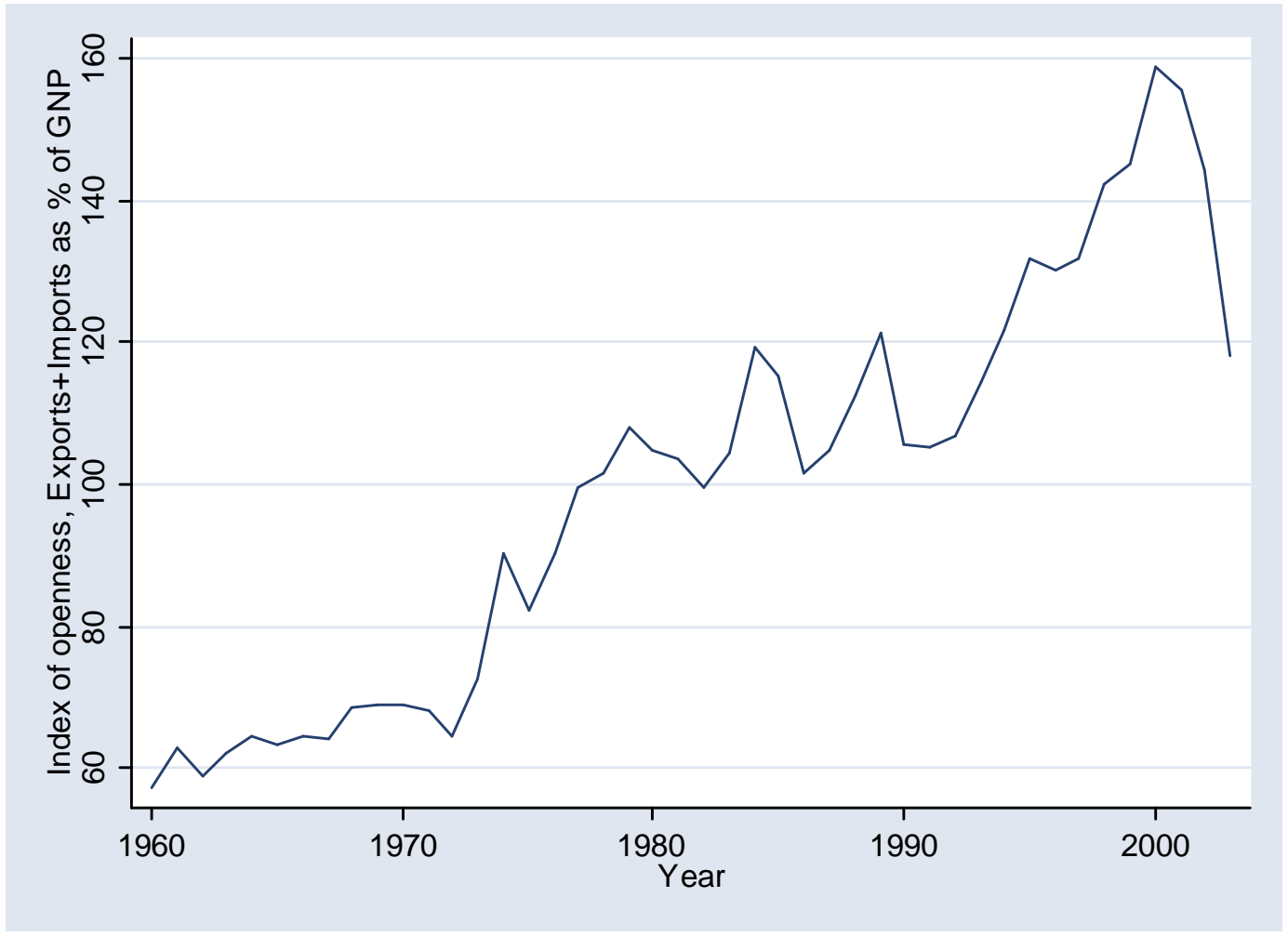

Source: CSO and ESRI Databank 
Fig. 2. Index of Economic Openness.

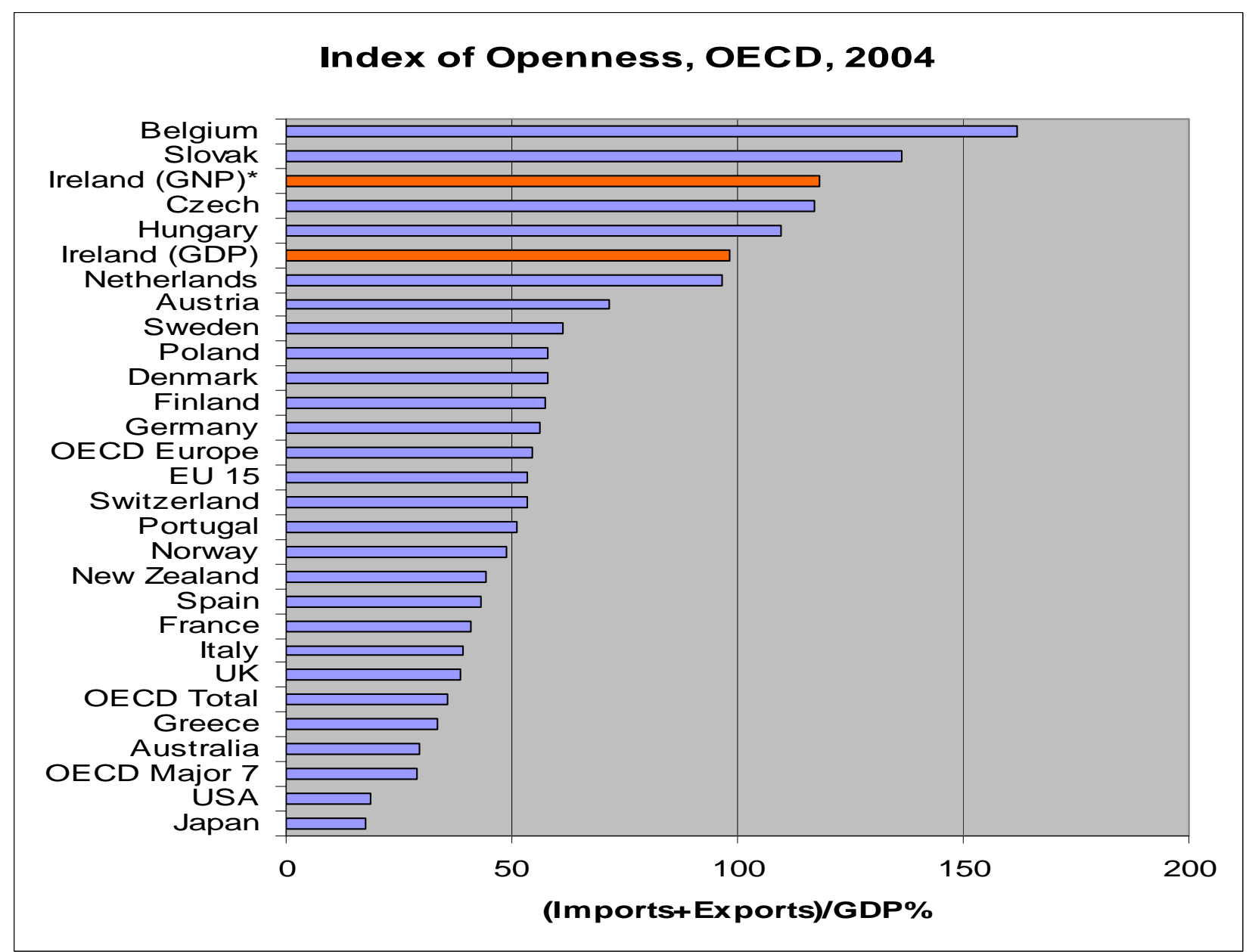

Source: OECD Economic Outlook, 2004. 
Fig. 3. Irish Government Current Expenditure, Current Market Prices, €m.

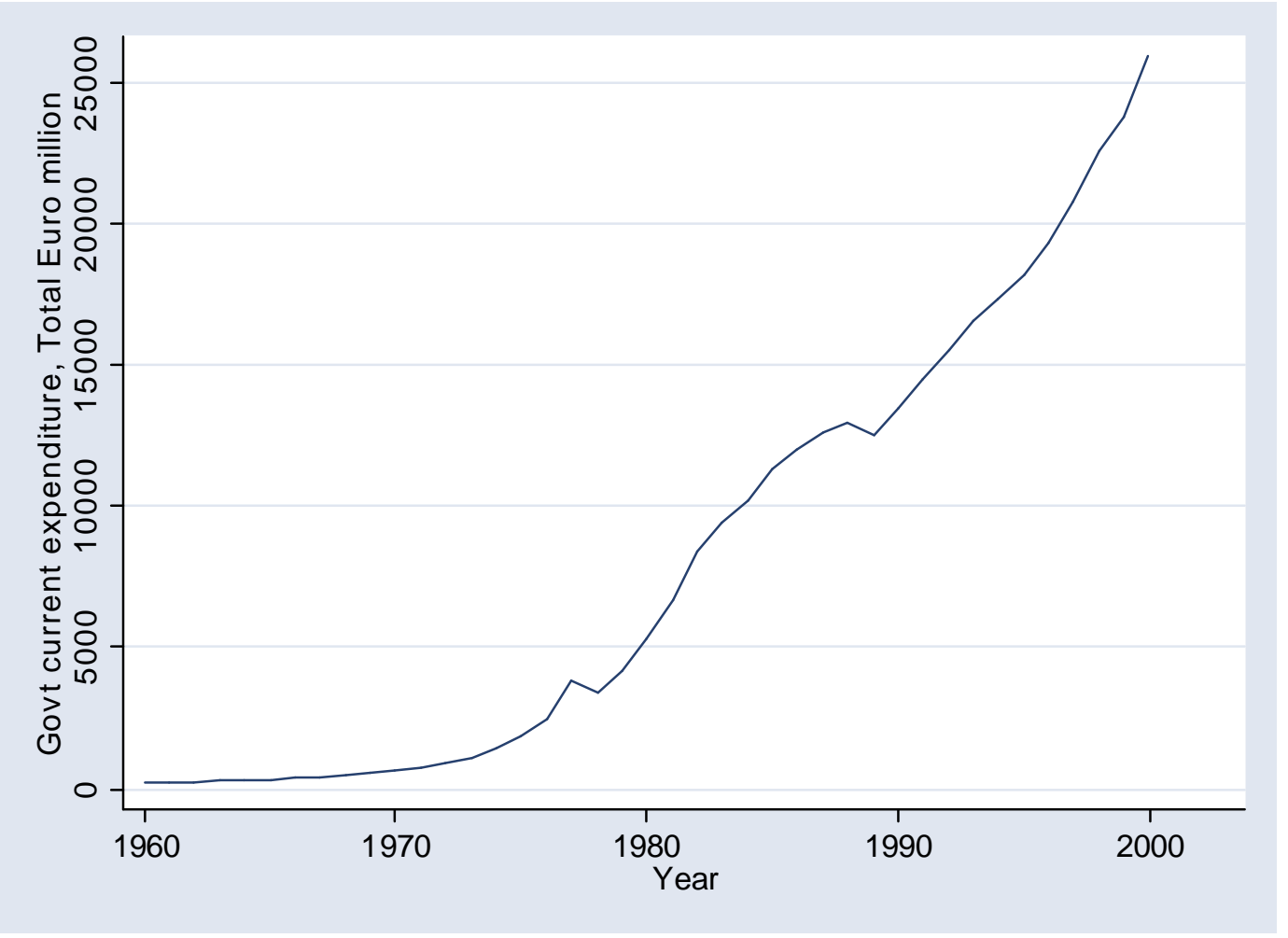

Source: ESRI Databank 
Fig. 4. Government Consumption Expenditure as \% of GDP, 2003.

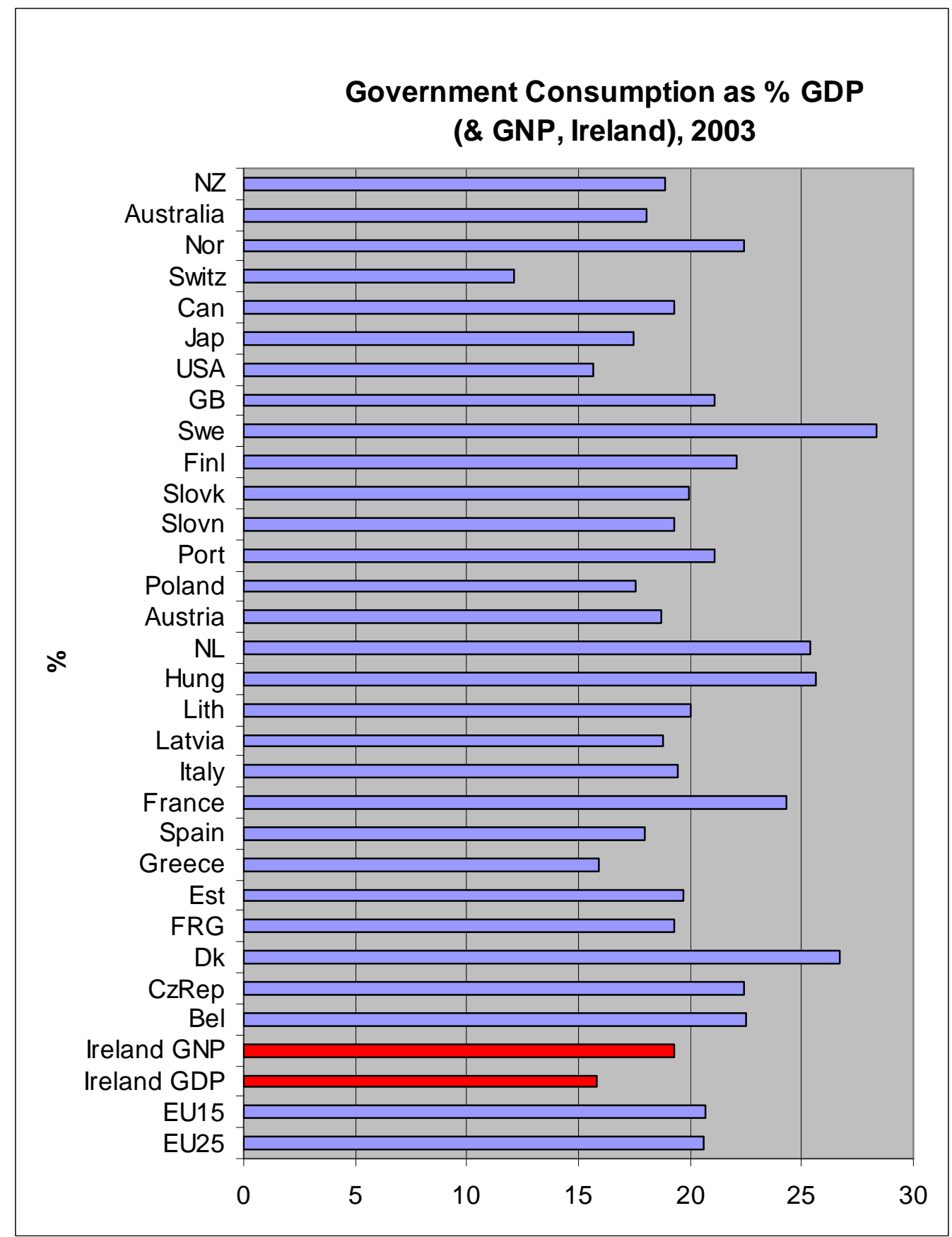

Source: Calculated from EU AMECO database. http://europa.eu.int/comm/economy_finance/indicators/annual_macro_economic_database/a meco_contents.htm

Item 2 (Consumption), variable UCTG, 'Total final consumption expenditure of central government'; and item 7 (Domestic Product and Income), variable 'GDP'. Both series in ECU/Euro. 
GNP for Ireland 2003: Department of Finance estimate, Economic and Budgetary Statistics 2004, Table 12. 
Fig. 5. Government Consumption Expenditure as \% GDP, Selected Countries, 1960-2003.

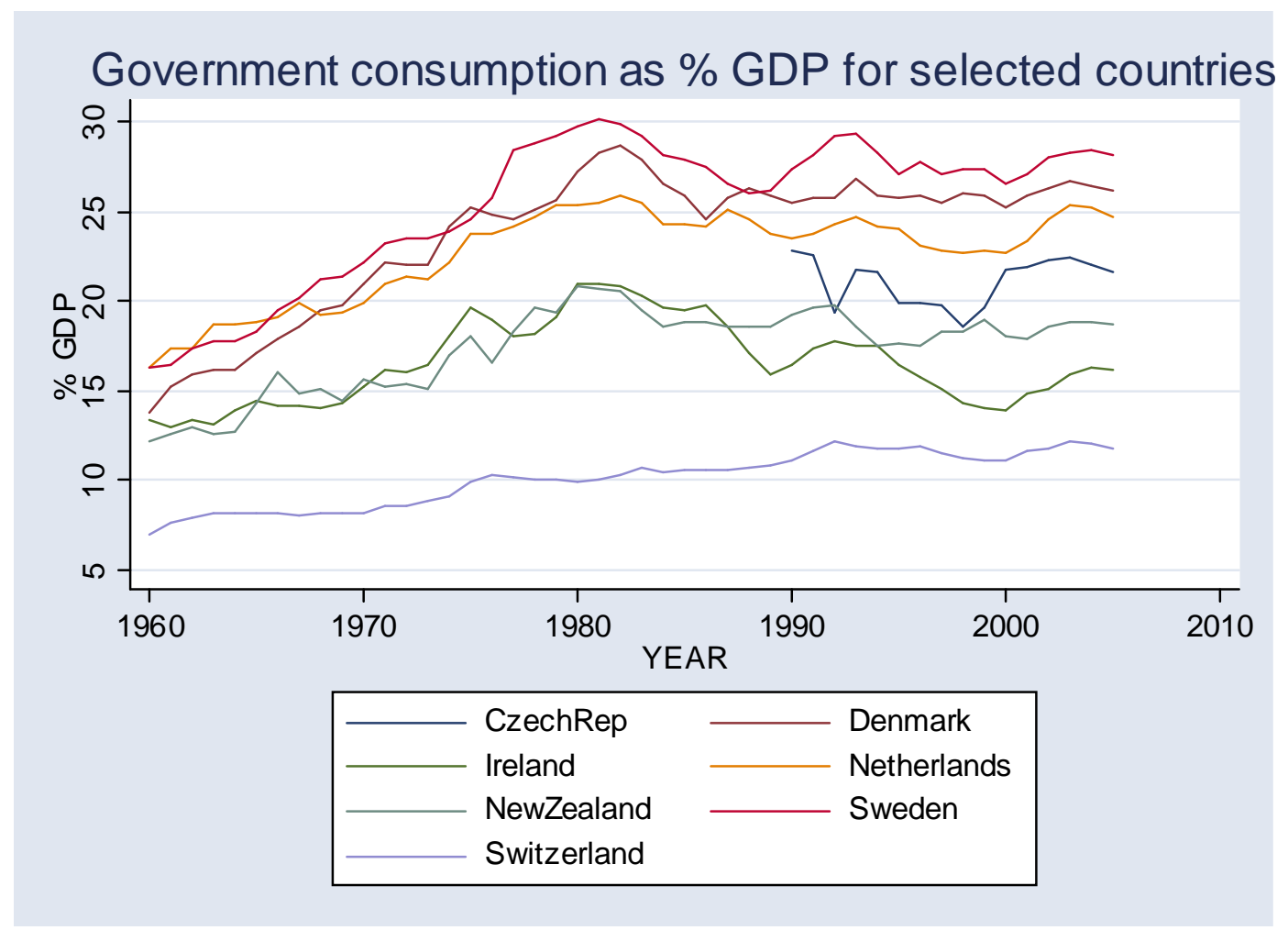

Source: Calculated from EU AMECO database.

http://europa.eu.int/comm/economy_finance/indicators/annual_macro_economic_database/a meco_contents.htm

Item 2 (Consumption), variable UCTG, 'Total final consumption expenditure of central government'; and item 7 (Domestic Product and Income), variable 'GDP'. Both series in ECU/Euro.

GNP for Ireland 2003: Department of Finance estimate, Economic and Budgetary Statistics 2004, Table 12. 


\section{References}

Annett, Anthony. 2007. Lessons from Successful Labor Market Reformers in Europe. Washington DC: IMF.

Auer, Peter. 2000. Employment Revival in Europe: Labour Market Success in Austria, Denmark, Ireland and the Netherlands. Geneva: ILO.

Avdagic, Sabina, Martin Rhodes, and Jelle Visser. 2005. The Emergence and Evolution of Social Pacts: A Provisional Framework for Comparative Analysis. In Eurogov Governance Papers. http://www.connex-network.org/eurogov/pdf/egp-newgov-N-0501.pdf

Baccaro, Lucio, and Marco Simoni. 2002. The Irish Social Partnership and the "Celtic Tiger" Phenomenon. Geneva: International Labour Office.

Balcells Ventura, Laia. 2004. Trade Openness and Preferences for Redistribution. Can We Support the Compensation Hypothesis? In Estudios Working Paper 2004/209. Madrid: Juan March Institute.

Barro, R., and X. Sala-I-Martin. 1995. Economic Growth. Basingstoke/New York: Macmillan.

Barry, Frank, and John Bradley. 1997. FDI and Trade: the Irish Host-Country Experience. The Economic Journal 107:1798-811

Barry, Frank, John Bradley, and Eoin O'Malley. 1999. Indigenous and Foreign Industry. In Understanding Ireland's Economic Growth, edited by Frank Barry, 45-74.

Basingstoke: Macmillan.

Barry, Frank, and Stephen Weir. 2007. The Politics and Process of Trade Liberalisation in Three Small Peripheral European Economies. In GlobalEuroNet Workshop: Economic Convergence of Small Peripheral Countries in the Post-Second World War. Examples of Finland, Ireland and Portugal. Department of Social Science History, University of Helsinki, Finland.

Benoit, Kenneth, and Michael Laver. 2005. Mapping the Irish Policy Space: Voter and Party Spaces in Preferential Elections. Economic and Social Review 36 (2):83-108

Block, Fred. 2001. Introduction. In The Great Transformation: The Political and Economic Origins of our Time, edited by Karl Polanyi. Boston, MA: Beacon Press.

Blyth, Mark. 2002. Great Transformations: Economic Ideas and Institutional Change in the Twentieth Century. Cambridge: Cambridge University Press.

Bradley, John. 2000. The Irish Economy in Comparative Perspective. In Bust to Boom? The Irish Experience of Growth and Inequality, edited by Brian Nolan, Philip J.

O'Connell, and Christopher. T. Whelan, 4-26. Dublin: IPA.

Bradley, John. 2004. Changing the Rules: How the Failures of the 1950 Forced a Transition in Economic Policy Making. Administration 52 (1) 
Breen, Richard, Damian F. Hannan, David Rottman, and Christopher. T. Whelan, eds. 1990. Understanding Contemporary Ireland: State, Class and Development in the Republic of Ireland. Dublin: Gill and Macmillan.

Calmfors, Lars, and John Driffill. 1988. Bargaining Structure, Corporatism and Macroeconomic Performance. Economic Policy Vol. 6 (April):13- 62

Cameron, David R. 1978. The Expansion of the Public Economy: A Comparative Analysis. The American Political Science Review Vol. 72 (4):1243- 61

Crouch, Colin. 2000. National Wage Determination and European Monetary Union. In After the Euro: Shaping Institutions for Governance in the Wake of European Monetary Union, edited by Colin Crouch. Oxford: Oxford University Press.

Curry, John. 2003. Irish Social Services. Dublin: IPA.

Dingeldey, Irene. 2007. Between Workfare and Enablement - The Different Paths to Transformation of the Welfare State: A Comparative Analysis of Activating Labour Market Policies. European Journal of Political Research 46 (6):823-51

Down, Ian. 2007. Trade Openness, Country Size and Economic Volatility: The Compensation Hypothesis Revisited. Business and Politics 9 (2, Article 3).http://www.bepress.com/bap/vol9/iss2/art3

FitzGerald, John. 2000. The Story of Ireland's Failure - and Belated Success. In Bust to Boom? The Irish Experience of Growth and Inequality, edited by Brian Nolan, Philip J. O'Connell, and Christopher. T. Whelan, 27-57. Dublin: IPA.

Garrett, Geoffrey. 1993. The Politics of Structural Change: Swedish Social Democracy and Thatcherism in Comparative Perspective. Comparative Political Studies 25 (4):52147

Garrett, Geoffrey. 1995. Capital Mobility, Trade, and the Domestic Politics of Economic Policy. International Organization 49 (4):657-87

Garrett, Geoffrey. 1998. Partisan Politics in a Global Economy. Cambridge: Cambridge University Press.

Girvin, Brian. 1989. Between Two Worlds: Politics and Economic Development in Independent Ireland. Dublin: Gill and Macmillan.

Gunnigle, Patrick, David G. Collings, and Michael Morley. 2005. Exploring the Dynamics of Industrial Relations in US Multinationals: Evidence from the Republic of Ireland. Industrial Relations Journal 36 (3):241-56.http://www.blackwell-synergy.com/loi/irj

Hall, Peter A. 1997. The Role of Interests, Institutions and Ideas in the Comparative Political Economy of the Industrialized Nations. In Comparative Politics: Rationality, Culture, and Structure, edited by Mark Irving Lichbach, and Alan S. Zuckerman, 174-207. Cambridge: Cambridge University Press.

Hall, Peter A., and Daniel W. Gingerich. 2004. Varieties of Capitalism and Institutional Complementarities in the Macro-economy: An Empirical Analysis. In Max Planck Institute for the Study of Societies Discussion Paper 04/5. Cologne: Max Planck Institute for the Study of Societies http://www.mpifg.de/pu/mpifg_dp/dp04-5.pdf 
Hall, Peter A., and David Soskice, eds. 2001. Varieties of Capitalism: The Institutional Foundations of Comparative Advantage. Oxford: Oxford University Press.

Hardiman, Niamh. 1988. Pay, Politics and Economic Performance in Ireland 1970-1987. Oxford: Clarendon Press.

Hardiman, Niamh. 2002. From Conflict to Coordination: Economic Governance and Political Innovation in Ireland. West European Politics 25 (4):1-24

Hardiman, Niamh. 2006. Politics and Social Partnership: Flexible Network Governance. Economic and Social Review 37 (3):347-74 http://www.esr.ie/Vol37_3/02\%20Hardiman.pdf

Hardiman, Niamh, Anthony McCashin, and Diane Payne. 2006. Understanding Attitudes to Poverty and Wealth. In Irish Social and Political Attitudes, edited by John Garry, Niamh Hardiman, and Diane Payne, 43-59. Liverpool: Liverpool University Press. http://www.ucd.ie/geary/publications/2004/wealth.pdf

Hardiman, Niamh, and Christopher. T. Whelan. 1994. Values and Political Partisanship. In Values and Social Change in Ireland, edited by Christopher. T. Whelan, 100-35. Dublin: Gill and Macmillan.

Hastings, Tim, Brian Sheehan, and Padraig Yeates. 2007. Saving the Future: How Social Partnership Shaped Ireland's Economic Success. Dublin: Blackhall Publishing Ltd.

Honohan, Patrick. 1992. Fiscal Adjustment in Ireland in the 1980s. The Economic and Social Review Vol. 23 (3):285- 314

Honohan, Patrick. 1999. Fiscal Adjustment and Disinflation in Ireland. In Understanding Ireland's Economic Growth, edited by Frank Barry. Basingstoke: Macmillan.

Iversen, Torben, and Anne Wren. 1998. Equality, Employment and Budgetary Restraint: The Trilemma of the Service Economy. World Politics 50 (4):507-46

Katzenstein, Peter J. 1985. Small States in World Markets: Industrial Policy in Europe. Ithaca, NY: Cornell University Press.

Katzenstein, Peter J. 2003. Small States and Small States Revisited. New Political Economy 8 (1):9-30

Kennedy, Kieran A., Tom Giblin, and Deirdre McHugh. 1988. The Economic Development of Ireland in the Twentieth Century. London: Routledge.

Kinderman, Daniel. 2005. Pressure from Without, Subversion from Within: the Two-Pronged German Employer Offensive. Comparative European Politics 3:432-63

Laver, Michael. 1992. Are Irish Parties Peculiar? In The Development of Industrial Society in Ireland, edited by John H. Goldthorpe, and Christopher. T. Whelan, 359-82. Oxford: Clarendon Press/ The British Academy.

Layte, Richard, Brian Nolan, and Christopher. T. Whelan. 2004. Explaining Poverty Trends in Ireland During the Boom. Irish Banking Review Summer 2004:2-14

MacCarthy, Charles. 1977. Trade Unions in Ireland 1894-960. Dublin: Institute of Public Administration. 
Maguire, Maria. 1984. Components of Growth of Income Maintenance Expenditure in Ireland, 1951-1979. The Economic and Social Review 15 (2):75-85

Mair, Peter. 1992. Explaining the Absence of Class Politics in Ireland. In The Development of Industrial Society in Ireland, edited by John H. Goldthorpe, and Christopher. T. Whelan, 383-410. Oxford: Oxford University Press.

McCashin, Anthony. 2004. Social Security in Ireland. Dublin: Gill and Macmillan.

Molina, Oscar, and Martin Rhodes. 2002. Corporatism: the Past, Present, and Future of a Concept. Annual Review of Political Science 5:305-31

Nolan, Brian, and Bertrand Maitre. 2007. Economic Growth and Income Inequality: Setting the Context. In Best of Times? The Social Impact of the Celtic Tiger, edited by Tony Fahey, Helen Russell, and Christopher T. Whelan, 27-42. Dublin: Institute of Public Administration.

O'Connell, Philip J. 2000. The Dynamics of the Irish Labour Market in Comparative Perspective. In Bust to Boom? The Irish Experience of Growth and Inequality, edited by Brian Nolan, Philip J. O'Connell, and Christopher. T. Whelan, 58-79. Dublin: Institute of Public Administration.

O'Connell, Philip J., and Helen Russell. 2007. Employment and the Quality of Work. In Best of Times? The Social Impact of the Celtic Tiger, edited by Tony Fahey, Helen Russell, and Christopher T. Whelan, 43-66. Dublin: Institute of Public Administration

O'Donnell, Rory, and Colm O'Reardon. 2002. Ireland: Recasting Social Partnership in a New Context. In Wage Policy in the Eurozone, edited by Philippe Pochet, 195-216. Brussels: PIE-Peter Lang.

O'Malley, Eoin. 1989. Industry and Economic Development: The Challenge for the Latecomer. Dublin: Gill and Macmillan.

O'Malley, Eoin. 2004. Competitive Performance in Irish Industry. ESRI Quarterly Economic Commentary Winter:66-101

O'Sullivan, Mary. 2000. Industrial Development: A New Beginning? In The Economy of Ireland: Policy and Performance of a European Region, edited by John W O'Hagan. Dublin: Gill and Macmillan.

Ó Gráda, Cormac. 1997. A Rocky Road: The Irish Economy Since the 1920s. Manchester: Manchester University Press.

Ó Riain, Seán. 2004. The Politics of High Tech Growth: Developmental Network States in the Global Economy. Cambridge: Cambridge University Press.

Olson, Mancur. 1971. The Logic of Collective Action: Public Goods and the Theory of Groups. Cambridge, MA: Harvard University Press.

Polanyi, Karl. 1944/1975. The Great Transformation. New York: Octagon Books.

Pontusson, Jonas. 1992. At the End of the Third Road: Swedish Social Democracy in Crisis. Politics and Society 20 (3):305- 32

Pontusson, Jonas, and Peter Swenson. 1996. Labor Markets Production Strategies, and Wage Bargaining Institutions : The Swedish Employer Offensive In Comparative Perspective. Comparative Political Studies 29 (2):233- 50 
Rhodes, Martin. 1998. Globalization, Labour Markets and Welfare States: A Future of 'Competitive Corporatism?' In The Future of European Welfare: A New Social Contract?, edited by Martin Rhodes, and Yves Mèny, 178-203. Basingstoke: Macmillan.

Rhodes, Martin. 2001. The Political Economy of Social Pacts: "Competitive Corporatism" and European Welfare Reform. In The New Politics of the Welfare State, edited by Paul Pierson. Oxford: Oxford University Press.

Roche, W.K, and J.F Geary. 2000. 'Collaborative Production' and the Irish Boom: Work Organisation, Partnership and Direct Involvement in Irish Workplaces. The Economic and Social Review 31 (1):1-36

Rodrik, Dani. 1998. Why do More Open Economies Have Bigger Governments? Journal of Political Economy 106 (5):997-1032

Ruggie, John G. 1997. Globalization and the Embedded Liberalism Compromise: The End of an Era. Cologne: Max Planck Institut für Gesellschaftsforschung.

Ruggie, John Gerard. 1982. International Regimes, Transactions, and Change: Embedded Liberalism in the Postwar Economic Order. International Organization 36 (2):379415

Scharpf, Fritz W. 1997. Games Real Actors Play: Actor-Centred Institutionalism in Policy Research. Boulder, CO: Westview Press.

Schmidt, Vivien A. 2003. How, Where and When does Discourse Matter in Small States' Welfare State Adjustment? New Political Economy 8 (1):127-46

Schwartz, Herman, and Uwe Becker. 2005. Introduction: Miracles, Mirages and Markets. In Employment 'Miracles': A Critical Comparison of the Dutch, Scandinavian, Swiss, Australian, and Irish Cases Versus Germany and the US, edited by Uwe Becher, and Herman Schwartz, 11-38. Amsterdam: Amsterdam University Press.

Soskice, David. 1999. Divergent Production Regimes: Coordinated and Uncoordinated Market Economies in the 1980s and 1990s. In Continuity and Change in Contemporary Capitalism, edited by Herbert Kitschelt, Peter Lange, Gary Marks, and John D. Stephens. Cambridge: Cambridge University Press.

Swenson, Peter. 1991. Labor and the Limits of the Welfare State : The Politics of Intraclass Conflict and Cross Class Alliances in Sweden and West Germany. Comparative Politics 23 (4):379- 99

Thelen, Kathleen. 2000. Why German Employers Cannot Bring Themselves to Dismantle the German Model. In Unions, Employers, and Central Banks, edited by Torben Iversen, Jonas Pontusson, and David Soskice, 138-72. Cambridge: Cambridge University Press.

Traxler, Franz. 2004. The Metamorphoses of Corporatism: From Classical to Lean Patterns. European Journal of Political Research 43:571-98

van Kersbergen, Kees. 1995. Social Capitalism: a Study of Christian Democracy and the Welfare State. New York: Routledge.

Whelan, Christopher T., Brian Nolan, and Bertrand Maitre. 2007. Consistent Poverty and Economic Vulnerability. In Best of Times? The Social Impact of the Celtic Tiger, 
edited by Tony Fahey, Helen Russell, and Christopher T. Whelan, 87-104. Dublin: Institute of Public Administration. 